Article

\title{
Reduction in Operating Costs and Environmental Impact Consisting in the Modernization of the Low-Power Cylindrical Wood Chipper Power Unit by Using Alternative Fuel
}

\author{
Łukasz Warguła * ${ }^{\mathbb{D}}$, Mateusz Kukla ${ }^{\mathbb{D}}$, Piotr Krawiec and Bartosz Wieczorek \\ Faculty of Mechanical Engineering, Institute of Machine Design, Poznan University of Technology, \\ 60-965 Poznań, Poland; mateusz.kukla@put.poznan.pl (M.K.); piotr.krawiec@put.poznan.pl (P.K.); \\ bartosz.wieczorek@put.poznan.pl (B.W.) \\ * Correspondence: lukasz.wargula@put.poznan.pl; Tel.: +48-(61)-665-20-42
}

Received: 18 May 2020; Accepted: 9 June 2020; Published: 10 June 2020

\begin{abstract}
Alternative fuel within the meaning of Directive 2014/94/EU is, among others, LPG (liquefied petroleum gas), characterized by a lower purchase cost and lower emissions of toxic exhaust compounds in comparison to the combustion of classic gasoline. In wood chippers, intended for chopping branches, with low-power internal combustion engines that meet the emission standards in force in 2019 in the European Union, in accordance with Regulation 2016/1628/EU, carburetor fuel supply systems are commonly used. Innovative trends in the development of these drives are: electronic fuel injection, systems supporting the adaptation of the working elements to the conditions of use and the use of alternative fuels. The first two solutions significantly affect the cost of purchasing a power unit or modernizing it. The authors of this article indicate, as a beneficial alternative, a cheap (EUR 105) possibility of modernizing the carburetor fuel supply system. It is based on a modification that will allow for the use of LPG instead of gasoline to drive the working system of the wood chipper. This article presents the results of tests on the fuel consumption of a wood chipper powered with gasoline (3.04 $\left.\mathrm{L} \mathrm{h}^{-1}\right)$ and LPG $\left(3.65 \mathrm{~L} \mathrm{~h}^{-1}\right)$ during continuous chipping. The cost of an hour of chipping related to fuel consumption was determined, which was equal to $3.89 € \mathrm{~h}^{-1}$ while using gasoline, and $2.19 € \mathrm{~h}^{-1}$ when using LPG. The mass flow rate $\left(0.66 \mathrm{th}^{-1}\right)$ and volumetric flow rate $\left(3.5 \mathrm{~m}^{3} \mathrm{~h}^{-1}\right)$ of a wood chipper powered by a low-power $(9.5 \mathrm{~kW})$ internal combustion engine with spark ignition were determined. In addition, we determined the cost of producing $1 \mathrm{~m}^{3}$ of biomass from chipping freshly cut oak branches (Quercus robur L. Sp. Pl. 996 1753) with a maximum diameter of $80 \mathrm{~mm}$ and a humidity of $25 \%$. The branches were selected earlier in such a way that their dimensions as as similar as possible. This amounted to EUR 1.11 for a gasoline-powered drive and EUR 0.63 for a LPG powered one. The benefits of using an alternative fuel supply system, the installation of which increases the cost of the machine by $8.4 \%$, have been confirmed.
\end{abstract}

Keywords: wood chipper; mass flow rate; volumetric flow rate; fuel consumption; non-road small engine; alternative fuels; LPG

\section{Introduction}

Mobile wood chippers, powered by non-road small engines, are usually intended for chipping branches with a maximum diameter of around $100 \mathrm{~mm}$. The engines of such machines are subject to legal regulations in the European Union (Regulation 2016/1628/EU) regarding the emission of toxic exhaust compounds [1]. These provisions are permissive in comparison with the emission requirements for vehicles, for example [2,3]. This contributes to the low technical sophistication of 
the design of the fuel supply systems for these power units [4,5]. From a review by Warguła et al., in 2018, it appears that $78 \%$ of commercially available engines were powered by gasoline, and in this group $89 \%$ were equipped with a carburetor fuel supply system [6]. Currently, work is underway to develop these power units towards the use of injection fuels [7-10], systems adapting the drive to the conditions of use [11,12], improving durability [13] and alternative fuels (LPG [14-18], ethanol [19,20] and methanol [21]). However, there are no regulations limiting the use of outdated technologies, and the relatively high cost of drives with the injection system is the result of their low popularity in the industry [4]. The authors of this article, noticing this problem, indicate a solution introducing innovation in this engine group through the use of alternative fuel. Construction, which has been tested in this study, has a low cost of implementation and can be used in both new solutions as well as those that are already being used.

The application of alternative fuel, which is LPG (Liquefied Petroleum Gas), according to Directive 2014/94/EU [22], allows for the reduction in the toxicity of exhaust gases [23-25]. The reduction of pollution emissions is necessary due to its direct impact on humans [26,27]. Research is conducted around the world on the level of the emissions of toxic exhaust compounds generated by internal combustion engines powering non-road mobile equipment and their impact on the environment and operators [28-33]. In this context they also relate to wood chippers [34]. Research conducted in China in 2016 showed that the PM2.5 dust emission from road vehicles amounted to 123,000 $t$, and non-road equipment drives generated 38,000 $\mathrm{t}$ [35]. Despite the passage of several years, researchers from China still estimated a similar value of this emission at 38,800 $\mathrm{t}$ in 2019 [36]. This value includes emissions related to low-power wood chippers, which are the subject of this paper. They are not suitable for biomass production on a large scale; however, they are very popular, especially in cleaning works in urban areas. Guo et al. predict a further increase of $6 \%$ in 2020 and $9 \%$ in 2025 . The reason for this phenomenon is the increase in the mechanization of agriculture and the dynamic development of the construction industry [36]. The results of research conducted in the USA in 2006 testify to the fact that operators of machines powered by classic construction engines may be exposed to much higher levels of CO gases and PM2.5 dusts during their work [37]. This means that the emissions generated by this type of equipment cannot be ignored, because they are not only a part of global emissions, but are also locally significant as a real threat to people's lives and health in the workplace.

Air pollution concentrations in urban areas around the world are important and actual problems. The standards of air quality are exceeded in most major cities on all continents: Australia [38], South America [39], North America [40], Asia [41], Africa [42] and Europe [43]. This situation is one of the reasons for dysphoria [44,45], loss of physical-motion capacity [46], loss of health [47,48] but also contributes to the development of oncological diseases [49] and premature death [50,51]. Scientists are increasingly recognizing the relationship between human health and air pollution. Research is also being conducted among professional groups in which the nature of work is related to being in an environment polluted by exhaust gases from machine drives. Such research concerns various industries: agriculture (e.g., tractor operators) [52]; forestry (e.g., chainsaw operators) [33]; people working in the mining industry [53]; people working in the vicinity of power generators [54]. All of these studies indicate that people working in these conditions are subjected to elevated concentrations of pollutants, which may translate into increased pathogenic tendencies [55]. Limiting the quantitative emission of exhaust gases and limiting the toxic exhaust compounds within them is beneficial for the environment and the people surrounding the machinery emitting pollutants. It also presents benefits for industry and state organs whose employees and citizens, exposed to lower emissions, may be characterized by better health and psychophysical status, and thus would be more efficient at work.

Most of the available tests for fuel consumption and the efficiency of wood chipping processes are carried out on high-power machines with compression-ignition (CI) engines, as shown in Figure 1 [56-84]. The term "small engines" applies only to spark ignition engines when they are used in chipping machines (due to operating conditions) of power lower than $19 \mathrm{~kW}$ [1]. Provisions regarding non-road mobile equipment with compression-ignition (CI) engines apply to engines without 
defined restrictions regarding the power of the power unit. Instead, they introduce a division into different research cycles, depending on the power of the engine [1]. However, in the literature there are available research results for wood chippers that are defined as low power (209 kW) and medium power $(559 \mathrm{~kW})$ [85]. The analyses related to these machines mainly concern the impact of:

- material

- $\quad$ part of a tree (trunk or branches) $[64,65,67,70,72,77,80,82,84]$

- tree species (soft or hard wood) $[60,62,64-67,72,78,79,86]$

- $\quad$ wood humidity (fresh or dry) $[64,70,72,87]$

- machine

- $\quad$ type of working element $[58,67,68,80,84]$

- $\quad$ power unit (high power or low power, industrial) $[67,73,84,85]$

- wear of knife blades $[58,59,61,65-68,76,79,88]$

- $\quad$ size of the sieves $[65,69,77,85,86]$

- $\quad$ average productivity $[56,63,66,70,71,73,74,80,81,89,90]$

- $\quad$ wood chips

- $\quad$ size of wood chips $[56,63-65,71,72,76,80,86,90,91]$

- method and frequency of feeding of chipped material

- feeding system (feeder [62,80] or operator [11])

- $\quad$ space and terrain topology during the works on chipping processes [75].

There is a lack of analysis of the impact of power unit selection on wood chopping processes. The authors are also not familiar with research related to the average productivity and fuel consumption of low-power chipping machines powered by spark ignition engines. The vast majority of tests are carried out on drum chippers [57-63,65-67,69-75,77,79,80,84], disc chippers [56,67,68,74,76,80,81,83,84,92], hammer chippers [80,84] or spiral chippers [74]. There is a lack of analysis of cylindrical chippers. A small number of studies related to cylindrical chippers can also be noted.
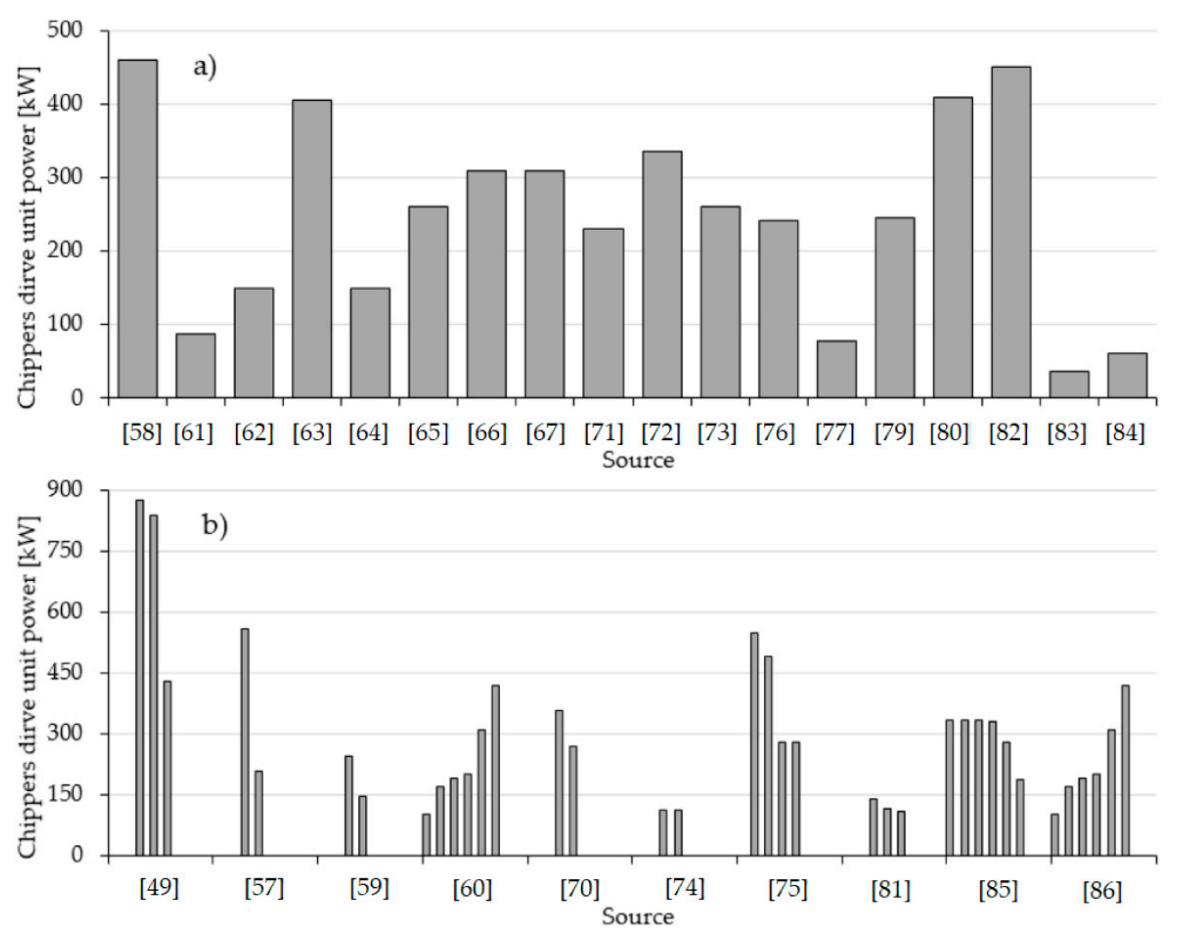

Figure 1. Power of wood chipper power units tested in scientific papers; (a) papers referring to one chipper, (b) papers referring to more than one chipper. 
The purpose of the paper is to compare the fuel consumption of a cylindrical chipper with a low-power engine powered classically by gasoline and-after modernization—by alternative fuel. The authors indicate a relatively cheap way of modernizing the machine, bringing ecological and economic benefits. The paper presents current research on the machines, representing the current state of technology and the industry, dealing with the green infrastructure of urban areas. In the future, these results will be a reference for the development of innovative solutions.

LPG installations are not applicable in all mobile machines, among others, due to the mass and size of gas tanks. The difficult applicability of LPG installations for small drives is characterized by their limited use. The authors used LPG installations in the low-power engine of a mobile machine, in which there were no significant difficulties in operation. This contributes to the widespread use of alternative fuels that are more environmentally friendly. This is the only such solution known to the authors in machines of this kind. The presented research results have an additional advantage; they are the answer to one of the problems of low-power wood chipper users. Based on the literature, there was a lack of knowledge regarding the operational parameters of these machines independent of their manufacturers.

This article presents the results of tests on a cylindrical chipper powered by a low-power motor $(9.5 \mathrm{~kW})$. During the experiments, fuel consumption during the chipping process was determined, depending on the fuel supply system used. In the first stage of research, the fuel consumption of the chipper powered by gasoline engine, equipped with carburetor power supply system, was determined. In the second stage, a chipper, equipped with an LPG supply system, was tested. During the experiments, the average productivity of the tested machine was determined. For this purpose, the mass and volumetric flow rate values were determined in order to evaluate this parameter. Operating costs were also included, taking fuel prices into account.

\section{Materials and Methods}

The subject of performed research was a Red Dragon RS-100 wood chipper [93], its unmodified version presented in Figure 2a, driven by a German GX $390 \mathrm{OHV}(9.5 \mathrm{~kW})$ four-stroke spark-ignition engine [94], its unmodified version depicted in Figure 2b, and engine specification presented in Table 1. The factory configuration version (A) uses a carburetor fuel feed system, and is intended for processing wood waste and branches with a diameter of up to $80 \mathrm{~mm}$ [93]. The unmodified gasoline-powered carburetor is shown in Figure 2c. Then, the original design (A) was modernized to the second version (B). In version (B) the carburetor powered by gasoline was replaced by a carburetor system adapted to use a mixture of propane and butane as fuel. The modified carburetor powered by LPG is presented in Figure 3b [95]. A cylindrical chipper with a drive equipped with an LPG system is shown in Figure 3a.

The engine in configuration A was supplied with petrol and the engine in configuration B with LPG, the selected physicochemical properties of which are shown in Table 2 [96]. The provided data refer to the International Standard Metric Conditions for natural gas and similar fluids (ISO 13443:1996) and are defined for $288.15 \mathrm{~K}\left(15^{\circ} \mathrm{C}\right)$ and $101.325 \mathrm{kPa}$.

Table 1. Technical specification of German GX390 engine.

\begin{tabular}{cc}
\hline Parameter & Characteristic \\
\hline Swept volume & $389 \mathrm{~cm}^{3}$ \\
Engine maximal power at $3600 \mathrm{rpm}$ & $9.56 \mathrm{~kW} / 13 \mathrm{HP}$ \\
Engine maximal torque at $2500 \mathrm{rpm}$ & $26.5 \mathrm{Nm}$ \\
Bore/Stroke & $88 \mathrm{~mm} / 64 \mathrm{~mm}$ \\
Engine Type & Four-stroke, OHV (Over Head Valve) \\
Number of cylinders & 1 \\
Ignition & Electronic, without ignition timing adjustment [97] \\
Weight & $31 \mathrm{~kg}$ \\
Average cost & EUR 270 \\
\hline
\end{tabular}


Table 2. Properties of tested fuels, where $\mathrm{MON}=$ motor octane number; $\mathrm{RON}=$ research octane number [96].

\begin{tabular}{|c|c|c|}
\hline Fuel & Gasoline 95 & $\begin{array}{l}\text { Liquefied Petroleum Gas } \\
\text { Propane-Butane } 50 \% / 50 \%\end{array}$ \\
\hline $\begin{array}{l}\text { Density under reference conditions } \\
\text { (liquid phase) }\left[\mathrm{kg}\left(\mathrm{m}^{3}\right)^{-1}\right]\end{array}$ & $720-775$ & 520 \\
\hline Fuel calorific value $\left[\mathrm{MJ} \mathrm{kg}^{-1}\right]$ & 42.6 & 46 \\
\hline Boiling temperature $\left[{ }^{\circ} \mathrm{C}\right]$ & $40-210$ & -30 \\
\hline $\begin{array}{l}\text { Excess air coefficient } \lambda \text { up to the } \\
\text { ignitability boundaries }\end{array}$ & $0.4-1.4$ & $0.4-1.7$ \\
\hline Octane number MON (RON) & $85(95)$ & $95(100)$ \\
\hline Air fuel ratio (AFR) for stoichiometric mix & $14.7: 1$ & $15.5: 1$ \\
\hline
\end{tabular}

The research was carried out on freshly cut branches of oak (Quercus robur L. Sp. Pl. 996 1753) with a diameter in the largest cross-section amounting to approximately $80 \mathrm{~mm}$ and a humidity at around $25 \%$. The specimens that underwent the tests are a representative of hard wood species in accordance with Janka classification [98].

The measurement of actual fuel consumption was taken using the mass method $[99,100]$. The measurement consisted of measuring the weight of the tank with fuel $m_{e}$, performing work under the predefined operating conditions and then reading the level of fuel consumption, which yielded an accuracy of $\pm 0.001 \mathrm{~kg}$.

The tests were carried out in two stages. During the first stage, it was carried out in set exploitation conditions:

- $\quad$ idling at low speed;

- idling with maximum torque;

- operation through a continuous chipping process.

The carried out statistical analysis consisted of performing the distribution normality test using the Shapiro-Wilk method, rejecting excessive errors using the Chauwenet method and determining the standard deviation for the mean of the measurements. For the measurement tests results, the mean value was calculated, taking into account the corrections according to Student's $t$ distribution for the 95\% confidence level, as shown in Tables 1 and 2 [101-104].

The efficiency of wood chip production (in terms of capacity) was measured using two methods. The first method was based on measuring the time of $t$ filling the container with a volume of $V=120 \mathrm{~L}$, while the other involved measuring the weight of $m$ filled containers. This way, the results of the volumetric $Q$ and mass $Q_{m}$ flow rates of the tested cylindrical chipper were obtained. The tests were carried out in 10 replications. Statistical analysis was performed at the significance level set at $\alpha=0.05$. The Anderson-Darling test was used to determine the normality of the distribution of measured data. 

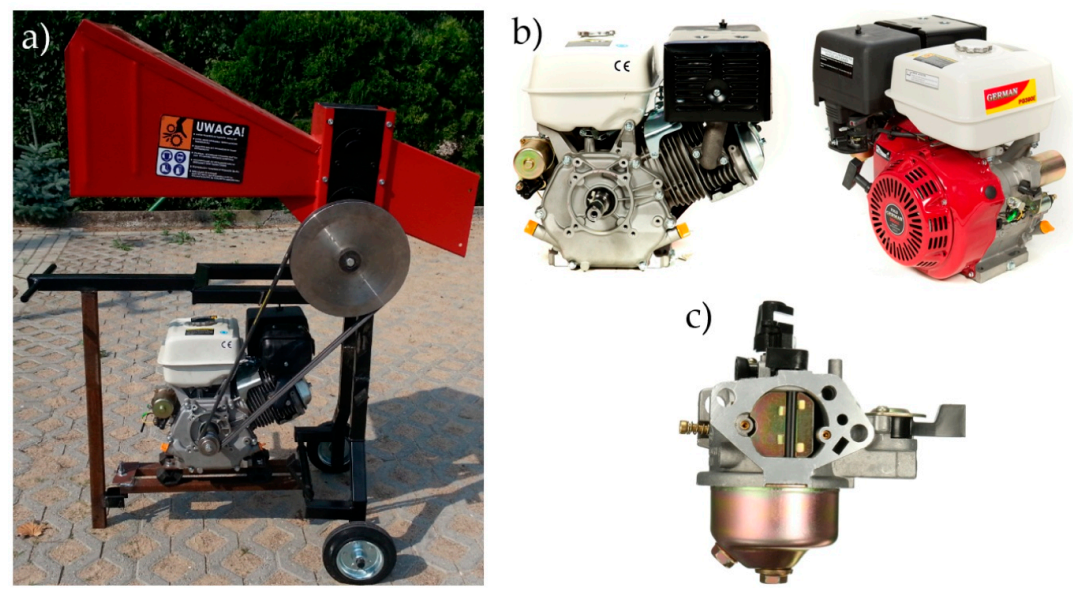

Figure 2. View of the unmodified Red Dragon RS-100-type cylindrical chipper and its components: (a) chipper with German GX 390 type engine attached, (b) unmodified German GX 390 type engine, (c) unmodified gasoline-powered carburetor.
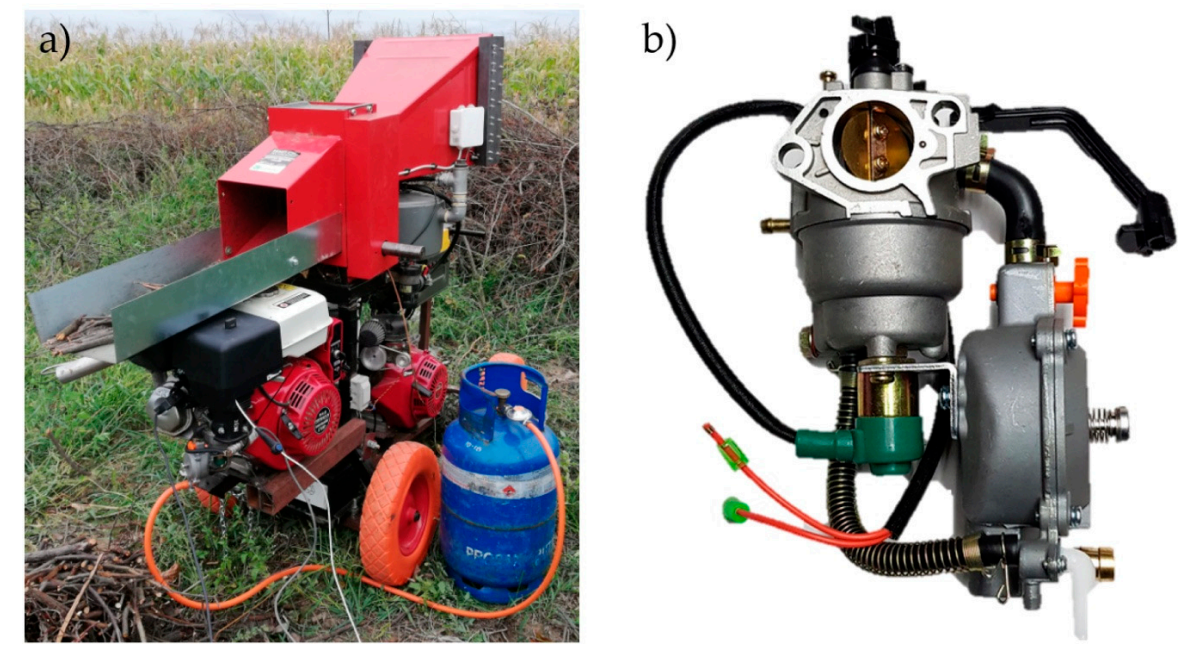

Figure 3. View of the modified Red Dragon RS-100 type cylindrical chipper and its components: (a) chipper with German GX 390 type engine after fuel supply system modification, (b) modified carburetor powered by LPG (in the "a" picture, two engines are mounted in the wood chipper, but only the one connected to the cylinder took part in the tests).

\section{Results}

\subsection{Fuel Consumption}

The results of the fuel consumption test for the cylindrical chipper powered by a gasoline and LPG combustion engines are presented in Table 3. 
Table 3. The fuel consumption of the cylindrical chipper: A-with a gasoline powered engine; B-with an LPG powered engine. AVG, arithmetic average; SD, standard deviation of the mean; I, incertitude limits by Student's t distribution for a 95\% confidence level.

\begin{tabular}{|c|c|c|c|c|c|c|}
\hline \multirow[t]{2}{*}{ Test No. } & \multicolumn{2}{|c|}{$\begin{array}{c}\text { Idle Work with Low } \\
\text { Rotational Speed }\left[\mathrm{kg} \mathrm{h}^{-1}\right]\end{array}$} & \multicolumn{2}{|c|}{$\begin{array}{c}\text { Idle Work with High } \\
\text { Rotational Speed }\left[\mathrm{kg} \mathrm{h}^{-1}\right]\end{array}$} & \multicolumn{2}{|c|}{$\begin{array}{c}\text { Continuous } \\
\text { Chipping }\left[\mathrm{kg} \mathrm{h}^{-1}\right]\end{array}$} \\
\hline & A & B & A & B & A & B \\
\hline 1 & 0.455 & 0.375 & 0.887 & 0.752 & 2.319 & 1.823 \\
\hline 2 & 0.470 & 0.345 & 0.875 & 0.782 & 2.521 & 1.945 \\
\hline 3 & 0.432 & 0.331 & 0.929 & 0.811 & 2.287 & 2.011 \\
\hline 4 & 0.443 & 0.389 & 0.921 & 0.862 & 2.312 & 1.954 \\
\hline 5 & 0.454 & 0.353 & 0.892 & 0.798 & 2.274 & 1.887 \\
\hline 6 & 0.443 & 0.412 & 0.935 & 0.743 & 2.509 & 1.898 \\
\hline 7 & 0.466 & 0.375 & 0.859 & 0.815 & 2.292 & 1.789 \\
\hline 8 & 0.481 & 0.385 & 0.923 & 0.832 & 2.141 & 1.873 \\
\hline 9 & 0.429 & 0.394 & 0.935 & 0.843 & 2.648 & 1.923 \\
\hline 10 & 0.431 & 0.388 & 0.944 & 0.773 & 2.251 & 1.902 \\
\hline AVG & 0.450 & 0.375 & 0.914 & 0.801 & 2.311 & 1.901 \\
\hline SD & 0.0056 & 0.0078 & 0.0092 & 0.0123 & 0.0485 & 0.0203 \\
\hline I & 0.013 & 0.017 & 0.021 & 0.027 & 0.108 & 0.045 \\
\hline
\end{tabular}

\subsection{Average Productivity of the Chipping Process}

The results of the average productivity test of the branch chipping process using the cylindrical wood chipper are presented in Table 4 . The tested power units were characterized by a similar power value, and the type of fuel burned did not affect the waste cutting process. For this reason, the results are not broken down into the type of fuel used to power the chipper.

Table 4. Values obtained as a result of measurements and statistical data. AVG, arithmetic mean; SD, standard deviation of the arithmetic mean; $p_{v a l}$, test probability for the Anderson-Darling test.

\begin{tabular}{ccc}
\hline Test No. & Mass $\boldsymbol{m}[\mathbf{k g}]$ & Time $\boldsymbol{t}[\mathbf{h}]$ \\
\hline 1 & 24.50 & 0.0220 \\
2 & 19.50 & 0.0233 \\
3 & 21.50 & 0.0380 \\
4 & 27.50 & 0.0405 \\
5 & 21.00 & 0.0382 \\
6 & 21.50 & 0.0425 \\
7 & 20.00 & 0.0428 \\
8 & 22.50 & 0.0350 \\
9 & 26.10 & 0.0258 \\
10 & 22.40 & 0.0350 \\
AVG & 22.65 & 0.0343 \\
SD & 2.61 & 0.0078 \\
$p_{\text {val }}$ & 0.32 & 0.1124 \\
\hline
\end{tabular}

The volumetric $Q$ and mass $Q_{m}$ flow rates of wood chip production during the experiment were determined using the relationship:

$$
\begin{aligned}
Q & =\frac{V}{t} \cdot\left[\mathrm{m}^{3} \cdot \mathrm{h}^{-1}\right] \\
Q_{m} & =\frac{m}{t} \cdot\left[\mathrm{kg} \cdot \mathrm{h}^{-1}\right]
\end{aligned}
$$

The recorded results were obtained for the continuous operation of the chipper (the chipping process continued uninterrupted). Based on the obtained data, after using relationships (1) and (2), it was determined that, in the considered process, the volumetric flow rate was $Q \approx 3.5 \mathrm{~m}^{3} \mathrm{~h}^{-1}$, while the mass flow rate was at a level of $Q_{m} \approx 660 \mathrm{~kg} \mathrm{~h}^{-1}$. Therefore, the density of the content of the wood 
chip container was $\rho=188.78\left[\mathrm{~kg}\left(\mathrm{~m}^{3}\right)^{-1}\right]$. This is apparent density because it takes into account the volume of voids in the container filled with air.

\section{Discussion}

The fuel consumption per hour of machine operation can be expressed in mass (3) or volume (4), as described by the correlations:

$$
\begin{gathered}
G_{e}=\frac{V_{p} \cdot \rho_{p}}{t}=\frac{m_{p}}{t} \cdot\left[\mathrm{kg} \cdot \mathrm{h}^{-1}\right] \\
G_{e}=\frac{m_{p}}{\rho_{p}} \cdot \frac{1}{t} \cdot\left[\mathrm{m}^{3} \cdot \mathrm{h}^{-1}\right]
\end{gathered}
$$

where: $V_{p}$ is the volume of fuel consumed during the measurement in $\left[\mathrm{m}^{3}\right], \rho_{p}$ is the density of the fuel under the measurement conditions in $\left[\mathrm{kg}\left(\mathrm{m}^{3}\right)^{-1}\right], \mathrm{t}$ is the fuel consumption time during the measurement in [h], and $m_{p}$ is the mass of fuel consumed during the measurement in $[\mathrm{kg}]$.

It is easier to estimate operating costs by using volumetric fuel consumption, as the tested fuels (gasoline and LPG) are widely sold in liters in the EU. A liter of 95 lead-free petrol at $15^{\circ} \mathrm{C}$ weighs an average of $0.76 \mathrm{~kg}$ (measurement in compliance with PN-EN ISO 12185 and PE-EN ISO 3675). Whereas $1 \mathrm{~L}$ of LPG in the liquid phase under the same conditions weighs $0.52 \mathrm{~kg}$, in accordance with PN-EN 589:2019-04. The values of fuel consumption during the working hours of the chipper are shown in Figure 4.
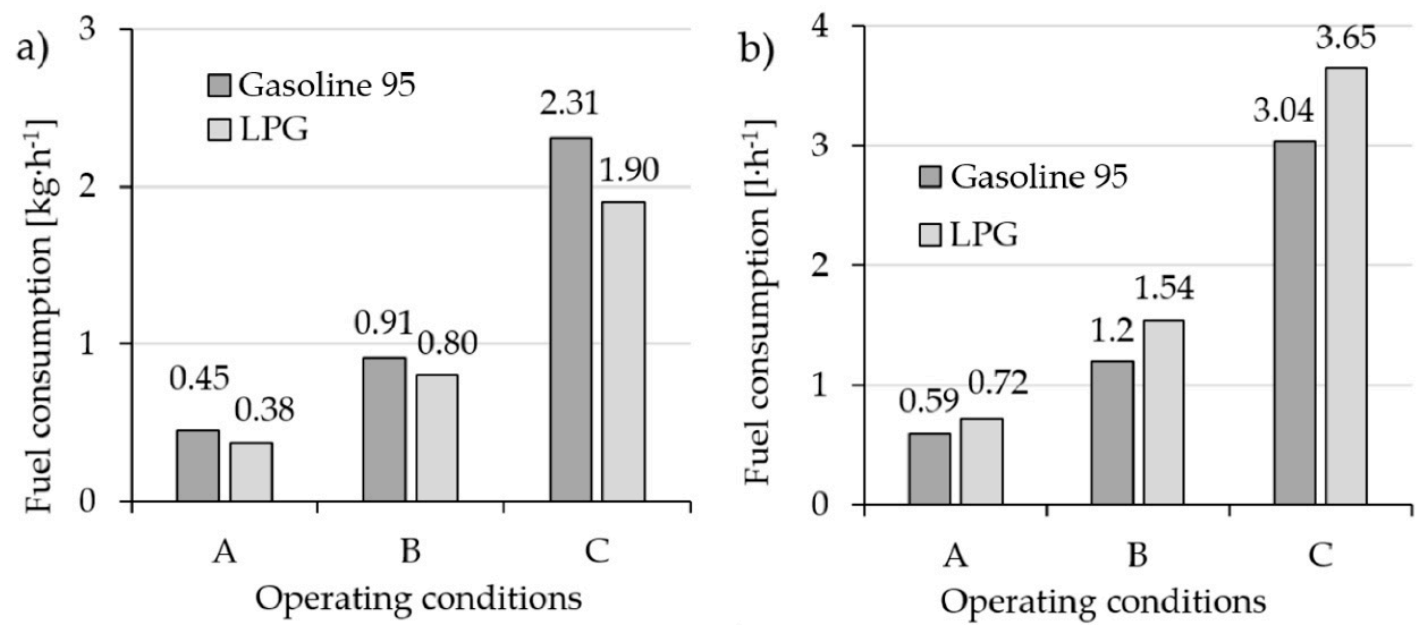

Figure 4. Consumption: (a) fuel mass per hour of operation, (b) fuel volume per hour of operation. A-Idling with low rotational speed of the drive, B-Idling with high rotational speed of the drive, C-chipping process.

The volumetric fuel consumption during LPG combustion increased by an average of approximately $23 \%$. This is consistent with the results of other research teams, whose test results showed an increase in fuel consumption when powering the LPG engine, relative to gasoline [105-107].

Fuel prices depend on many variables and change every day. In addition, these prices change differently, depending on the country and even region [108-110]. The authors set the average price in EUR for $1 \mathrm{~L}$ of fuel in Europe as of 10 January 2020, as shown in Figure 5. The average price of gasoline was $1.28 € \mathrm{~L}^{-1}$ and the price of LPG was $0.60 € \mathrm{~L}^{-1}$. This indicates that, during this period, gasoline was more than twice as expensive as LPG (about 113\%). These values were adopted for further analysis. The cost of an hour of chipping with a cylindrical chipper associated with fuel consumption was $3.89 € \mathrm{~h}^{-1}$ while combusting gasoline and $2.19 € \mathrm{~h}^{-1}$ when burning LPG. The conclusion is that, despite the higher fuel consumption, an hour of operation on the LPG powered chipping machine (continuous chipping) is about $44 \%$ cheaper. Machine operation in other states outside of the chipping process will also have a lower cost of use. 


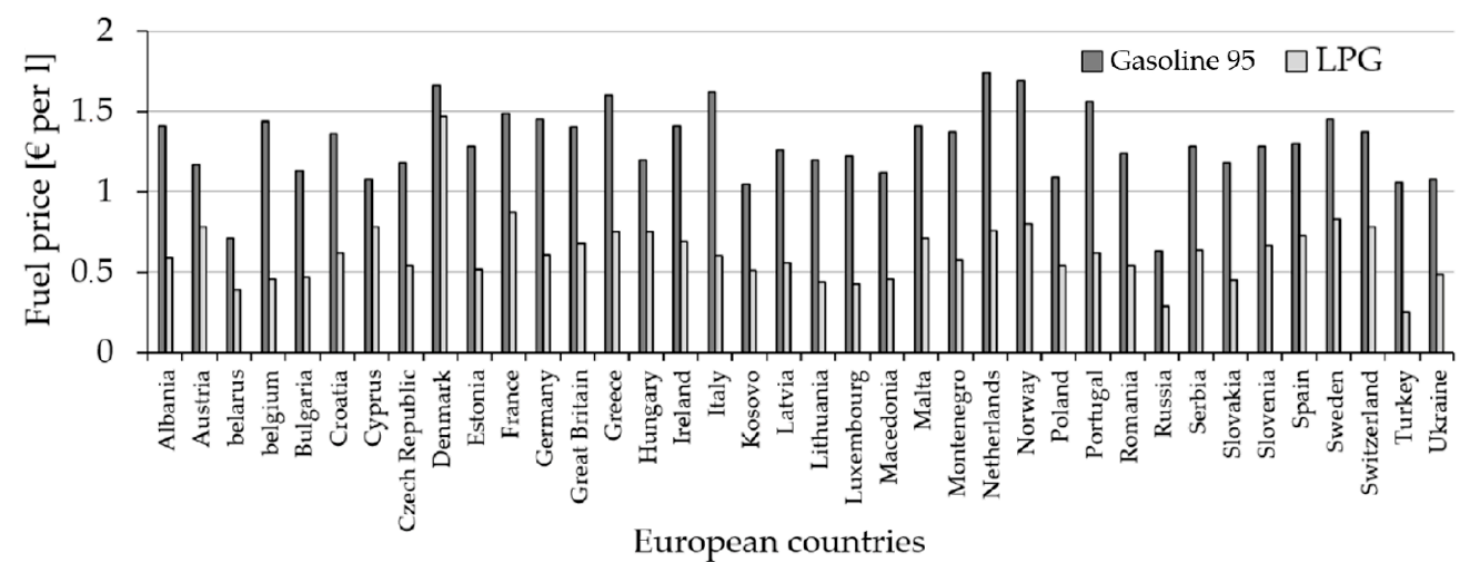

Figure 5. The price of gasoline and LPG in selected European countries, as of 10 January 2020.

The use of an installation enabling LPG combustion in small engines requires expenditures on the modernization of the construction. The cost of such modernization, according to the Table 5, amounts to EUR 105. The published data show that it can be expected that the expenditure incurred will pay for itself after about $65 \mathrm{~h}$ of operation, taking into only fuel costs into account. The cost of the cylindrical chipper presented in the study is EUR 1250, and modernization with an LPG system increases the cost of the machine by $8.4 \%$.

Table 5. Cost of components and services for modernizing a small engine to be powered by LPG.

\begin{tabular}{cc}
\hline System Components and Service & Cost \\
\hline Carburetor & $46 €$ \\
LPG gas reducer with pressure gauge & $7 €$ \\
Installation hose & $6 €$ \\
$11 \mathrm{~kg}$ gas tank & $23 €$ \\
Working time spent on the modernization of the structure and system regulation $1 \mathrm{~h}$ & $23 €$ \\
\hline
\end{tabular}

Chipping machine performance is strongly dependent on raw material, size of chips, type of working element and its settings, wear of knife blades, size of sieves and feeding system [74]. However, regardless of the factors mentioned, the hourly performance during the operation of such a machine, excluding all delays associated with the supply of material for a machine with a power in the range $205-430 \mathrm{~kW}$, is equal to $20-115 \mathrm{~m}^{3} \cdot \mathrm{h}^{-1}$, and the arithmetic average is about $70 \mathrm{~m}^{3} \cdot \mathrm{h}^{-1}[56,70,73]$. The volumetric flow rate of a small cylindrical chipper $(9.5 \mathrm{~kW})$ when chipping branches with dimensions constituting a heavy load is equal to $3.5 \mathrm{~m}^{3} \cdot \mathrm{h}^{-1}$. However, the mass flow rate of a cylindrical chipper with a low-power engine is equal to $0.66 \mathrm{t} \mathrm{h}^{-1}$ and, compared to the performance of an industrial chipper with a power of $335 \mathrm{~kW}$ and a mass flow rate of $43.8 \mathrm{t} \mathrm{h}^{-1}$ [81], is lower by about $98.5 \%$. It should be noted, however, that this is not a machine intended for the mass production of biomass.

The production cost of $1 \mathrm{~m}^{3}$ of biomass with a gasoline powered chipper is EUR 1.11, and for an LPG powered chipper it is EUR 0.63. For comparison, the production cost of $1 \mathrm{~m}^{3}$ of wood chips with high power chippers (205-407 kW) is between EUR 1.03 and EUR 2.38 [73]. The analysis indicates that chipping branches with low-power wood chippers does not generate increased costs of wood chip production. It is worth pointing out that the use of these machines can provide benefits during cleaning works, reducing the need to transport branches to large chipping machines.

The introduced change significance can be demonstrated on the basis of the recorded results. The relatively cheap and uncomplicated modification of the low-power chipper allows for an increase in the efficiency of its work in terms of fuel costs. The use of this solution in home gardens and other individual cases is characterized by a rather long investment return time. In this case, it would be more reasonable to purchase a chipper equipped with such a modification when the need arises. However, 
such a modification on a larger scale-for example, in a company serving urban green areas-will allow measurable economic benefits to be achieved within a reasonable period of time.

In addition, this research is part of the modern scientific trend related to powering the same machines with different fuels, showing the positive effects of using alternative fuels [111-114].

\section{Conclusions}

The presented study is currently the only one known to the authors offering empirical research results regarding chipping machines with low-power internal combustion engines. Data obtained from the test results of a cylindrical chipper powered by various types of fuel, along with the presentation of the costs of modernization, can support the process of estimating expenses in the forestry and fruit industries and industries dealing with the green infrastructure of urban areas. The results regarding fuel consumption and costs clearly indicate that the operating costs of low-power chipping machines can be reduced at a relatively low cost (cost of modernization is about EUR 105). For a new machine, the cost of installing alternative fuels increases its price by about $8.4 \%$. The introduced modernization utilizes the combustion of LPG fuel, the consumption of which is higher during the machine's hour of work by about $20 \%$ compared to the combustion of gasoline (Gasoline $95-3.04 \mathrm{~L} \mathrm{~h}^{-1} \mathrm{vs}$. LPG $3.65 \mathrm{~L} \mathrm{~h}^{-1}$ ). However, the price of one liter of LPG is, on average, more than half that of combustible gasoline in Europe. For example, in January 2020 it was about 113\% (Gasoline 95, $1.28 € \mathrm{~L}^{-1}$ vs. LPG, $\left.0.60 € \mathrm{~L}^{-1}\right)$. This contributes to lower costs, while chipping branches with the use of machines whose drive is powered by LPG, by about $44 \%$ (Gasoline $95,3.89 € \mathrm{~h}^{-1}$ vs. LPG, $2,19 € \mathrm{~h}^{-1}$ ). The determination of mass flow rate $\left(0.66 \mathrm{t} \mathrm{h}^{-1}\right)$ and volumetric flow rate $\left(3.5 \mathrm{~m}^{3} \cdot \mathrm{h}^{-1}\right)$ of the examined machine made it possible to determine the production costs of $1 \mathrm{~m}^{3}$ and $1 \mathrm{t}$ biomass with a chipper equipped with a $9.5 \mathrm{~kW}$ combustion engine. The cost of producing $1 \mathrm{~m}^{3}$ of biomass with a gasoline driven chipper is EUR 1.11, and for the LPG driven chipper it is EUR 0.63, while the cost of producing $1 \mathrm{t}$ of biomass with a gasoline powered drive is EUR 1.94, and for a chipper powered with LPG it is EUR 0.91. In addition, modernization reduces the negative impact on the natural environment and is part of the trend of the innovative powering of internal combustion engines with alternative fuels. The test results revealed that the mass and volumetric capacity of this type of wood chippers is relatively low. However, the main purpose of these machines is not the industrial production of shredded biomass, but the support of the clearing of wooded areas. Their task is to facilitate transport and, as a result, storage and composting and, ultimately, energy acquisition. Chipping in such conditions with tested machines does not generate higher production costs of wood chips. Development activities in the field of small machines and devices are important because these machines can have a great impact on the human body, the environment and the functioning of enterprises. Further research should be conducted in the field of exhaust emissions, the testing of developed constructions and their development into electronic control systems. In addition, the published results can be used to assess the costs of tree farming processes in urban areas.

Author Contributions: Conceptualization, Ł.W., P.K. and M.K.; methodology, Ł.W., M.K. and B.W.; software, Ł.W. and M.K.; validation, Ł.W., M.K. and P.K.; formal analysis, Ł.W., M.K., B.W. and P.K.; investigation, Ł.W., M.K., B.W. and P.K.; resources, Ł.W. and B.W.; data curation, Ł.W. and M.K.; writing-original draft preparation, Ł.W., M.K. and B.W.; writing-review and editing, M.K., P.K. and Ł.W.; visualization, M.K. and Ł.W.; supervision, Ł.W.; project administration, Ł.W.; funding acquisition, Ł.W. and B.W. All authors have read and agreed to the published version of the manuscript.

Funding: Research was performed as part of the project “Interdisciplinary Dean's Grant (IDG) of Poznań University of Technology" determined in the year 2020 for the subject-air quality in Poznan and how to improve it. Project title: "Design and research of mobile machines chipping wastes from urban agriculture processes for innovative construction solutions limiting the impact on the natural environment and machine operators" (33/32/SIGR/3334) financed by the Poznan University of Technology.

Conflicts of Interest: The authors declare no conflict of interest. 


\section{References}

1. EU. Regulation (EU) No 2016/1628 of the European Parliament and of the Council of 14 September 2016. On Requirements for Emission Limit Values of Gaseous and Particulate Pollutants and Type-Approval with Respect to Internal Combustion Engines for Mobile Machines Non-Road, Amending Regulations (EU) No 1024/2012 and (EU) No 167/2013 and Amending and Repealing Directive 97/68/WE; EU: Brussels, Belgium, 2016.

2. Waluś, K.J.; Warguła, Ł.; Krawiec, P.; Adamiec, J.M. Legal regulations of restrictions of air pollution made by non-road mobile machinery-The case study for Europe: A review. Environ. Sci. Pollut. Res. 2018, 25, 3243-3259. [CrossRef] [PubMed]

3. Mei, D.; Wang, H.; Dai, P.; Li, X. A statistical analysis of emission features in non-road small SI engines with the same displacement. Proc. Inst. Mech. Eng. Part D J. Automob. Eng. 2018, 232, 1431-1437. [CrossRef]

4. Warguła, Ł.; Waluś, K.J.; Krawiec, P.; Polasik, J. Electronic control injection-ignition systems in propulsion of non-road mobile machinery. J. Mech. Trans. Eng. 2018, 70, 61-78. [CrossRef]

5. Lavender, S. Small engine innovations-Current and future. In 17. Internationales Stuttgarter Symposium. Proceedings; Bargende, M., Reuss, H.C., Wiedemann, J., Eds.; Springer Vieweg: Wiesbaden, Germany, 2017; pp. 1567-1574.

6. Warguła, Ł.; Waluś, K.J.; Krawiec, P. Small engines spark ignited (SI) for non-road mobile machinery-Review. Transport means 2018. In Proceedings of the 22nd International Scientific Conference, Trakai, Lithuania, 3-5 October 2018; pp. 585-591.

7. Warguła, Ł. Innovative injection-ignition system in a non-road small engine-Construction system. In Proceedings of the 23rd International Scientific Conference, Palanga, Lithuania, 2-4 October 2019; pp. 931-935.

8. Warguła, Ł.; Krawiec, P.; Waluś, K.J.; Kukla, M. Conceptual design of adaptation of the mechanical fuel injection unit assembly for electronic control. Autobusy Technol. Eksploat. Syst. Transp. 2017, 12, 1381-1386.

9. Mahmoudzadeh Andwari, A.; Said, M.F.M.; Aziz, A.A.; Esfahanian, V.; Salavati-Zadeh, A.; Idris, M.A.; Perang, M.R.M.; Jamil, H.M. Design, modeling and simulation of a high-pressure gasoline direct injection (GDI) pump for small engine applications. J. Mech. Eng. 2018, 6, 107-120.

10. Niinikoski, J.; Ewalds, J.; Heikkinen, E.; Kotilainen, J.; Kääriäinen, M.; Tammi, K.; Kiviluoma, P.; Korhonen, A.; Kuosmanen, P. Methods for reducing emissions of small internal combustion engines. In Proceedings of the 11th International DAAAM Baltic Conference, Industrial Engineering, Tallinn, Estonia, 20-22 April 2016.

11. Warguła, Ł.; Waluś, J.K.; Krawiec, P. Determination of working conditions of mobile chipping wood machines in the aspect of innovative drive control systems. Sylwan 2019, 163, 765-772. [CrossRef]

12. Warguła, Ł.; Wojtkowiak, D.; Waluś, K.J.; Krawiec, P.; Wieczorek, B. The analysis of the efficiency of the control system of wood chipper's driver with spark-ignition engine based on Skoda combustion engine 1.459kW. In Proceedings of the 21st International Scientific Conference, Juodkrante, Lithuania, 20-22 September 2017; pp. 452-458.

13. Kim, H.C.; Park, K.; Nam, M.H.; Park, W.S. Analysis of component damage probability of a small engine based on penetration experiments and M \& S. J. Mech. Sci. Technol. 2020, 34, 765-775.

14. Li, L.; Wang, Z.; Deng, B.; Han, Y.; Wang, H. Combustion and emissions characteristics of a small spark-ignited LPG engine. SAE Technol. Pap. 2002. [CrossRef]

15. Li, L.; Liu, Z.; Wang, H.; Deng, B.; Wang, Z.; Xiao, Z.; Su, Y.; Jiang, B. Development of a gas-phase LPG injection system for a small SI engine. SAE Technol. Pap. 2003. [CrossRef]

16. Sulaiman, M.Y.; Ayob, M.R.; Meran, I. Performance of single cylinder spark ignition engine fueled by LPG. Procedia Eng. 2013, 53, 579-585. [CrossRef]

17. bin Mohd Zain, M.S.; bin Mohamed Soid, S.N.; bin Mior Abd Majid, M.F.; bin Zahelem, M.N. Performance characteristics of a small engine fueled by liquefied petroleum gas. In Advanced Engineering for Processes and Technologies. Advanced Structured Materials; Ismail, A., Abu Bakar, M., Öchsner, A., Eds.; Springer: Berlin/Cham, Germany, 2019; Volume 102, pp. 207-214.

18. Sabariah, M.S.; Nabilah, A.S.; Rosli, A.B.; Junaidi, Z.Z.; Mustafar, M.T. Analysis and simulation of combustion and emission on small engine. In IOP Conference Series: Materials Science and Engineering; UMP Pekan: Pahang, Malaysia, 2019; Volume 469. 
19. Schirmer, W.N.; Olanyk, L.Z.; Guedes, C.L.B.; Quessada, T.P.; Ribeiro, C.B.; Capanema, M.A. Effects of air/fuel ratio on gas emissions in a small spark-ignited non-road engine operating with different gasoline/ethanol blends. Environ. Sci. Pollut. Res. 2017, 24, 20354-20359. [CrossRef] [PubMed]

20. Ribeiro, C.B.; Martins, K.G.; Gueri, M.V.D.; Pavanello, G.P.; Schirmer, W.N. Effect of anhydrous ethanol/gasoline blends on performance and exhaust emissions of spark-ignited non-road engines. Environ. Sci. Pollut. Res. 2018, 25, 24192-24200. [CrossRef] [PubMed]

21. Gong, C.; Li, Z.; Huang, K.; Liu, F. Research on the performance of a hydrogen/methanol dual-injection assisted spark-ignition engine using late-injection strategy for methanol. Fuel 2020, 260, 116403. [CrossRef]

22. EU. Directive 2014/94/EU of the European Parliament and of the Council of 22 October 2014 on the Deploy-Ment of Alternative Fuels Infrastructure Text with EEA Relevance; EU: Strasbourg, France, 2014.

23. Szpica, D.; Czaban, J. Operational assessment of selected gasoline and LPG vapour injector dosage regularity. Mechanika 2014, 20, 480-489. [CrossRef]

24. Saraf, R.R.; Thipse, S.S.; Saxena, P.K. Comparative emission analysis of gasoline/LPG automotive bifuel engine. Int. J. Civ. Environ. Eng. 2009, 1, 199-202.

25. Tasic, T.; Pogorevc, P.; Brajlih, T. Gasoline and LPG exhaust emissions comparison. Adv. Prod. Eng. Manag. 2011, 6, 87-94.

26. Zeng, X.-W.; Vivian, E.; Mohammed, K.A.; Jakhar, S.; Vaughn, M.; Huang, J.; Zelicoff, A.; Xaverius, P.; Bai, Z.; Lin, S.; et al. Long-term ambient air pollution and lung function impairment in Chinese children from a high air pollution range area: The seven Northeastern cities (SNEC) study. Atmos. Environ. 2016, 138, $144-151$. [CrossRef]

27. Tang, G.; Zhao, P.; Wang, Y.; Gao, W.; Chang, M.; Xin, J.; Li, X.; Wang, Y. Mortality and air pollution in Beijing: The long-term relationship. Atmos. Environ. 2017, 150, 238-243. [CrossRef]

28. Czerwiński, J.; Kurzwart, M.; Mayer, A.; Comte, P. Particle emissions of modern handheld machines. $S A E$ Technol. Pap. 2014. [CrossRef]

29. Merkisz, J.; Lijewski, P.; Pielecha, J. PEMS-based investigations into exhaust emissions from non-road and rail vehicles. Combust. Engines 2016, 166, 46-53. [CrossRef]

30. Liu, S.; Han, W.; Zeng, J.; Wang, J. Analysis of combustion and emission characteristics of electronic controlled low pressure injected small gasoline engine. Trans. Chin. Soc. Agric. Eng. 2016, 32, 92-97. [CrossRef]

31. Dimou, V.; Anezakis, V.; Demertzis, K.; Iliadis, L.S. Comparative analysis of exhaust emissions caused by chainsaws with soft computing and statistical approaches. Int. J. Environ. Sci. Technol. 2017, 3-14. [CrossRef]

32. Lijewski, P.; Fuć, P.; Dobrzyński, M.; Markiewicz, F. Exhaust emissions from small engines in handheld devices. In MATEC Web of Conferences, VII International Congress on Combustion Engines, Poznań, Poland, 27-29 June 2017; EDP Sciences: Lez Ili, France, 2017; Volume 118.

33. Hooper, B.; Parker, R.; Todoroki, C. Exploring chainsaw operator occupational exposure to carbon monoxide in forestry. J. Occup. Environ. Hyg. 2017, 14, D1-D12. [CrossRef] [PubMed]

34. Magagnotti, N.; Picchi, G.; Sciarra, G.; Spinelli, R. Exposure of mobile chipper operators to diesel exhaust. Ann. Occup. Hyg. 2014, 58, 217-226. [PubMed]

35. Wang, F.; Li, Z.; Zhang, K.; Di, B.; Hu, B. An overview of non-road equipment emissions in China. Atmos. Environ. 2016, 132, 283-289. [CrossRef]

36. Guo, X.; Wu, H.; Chen, D.; Ye, Z.; Shen, Y.; Liu, J.; Cheng, S. Estimation and prediction of pollutant emissions from agricultural and construction diesel machinery in the Beijing-Tianjin-Hebei (BTH) region, China. Environ. Pollut. 2020, 113973. [CrossRef] [PubMed]

37. Baldauf, R.; Fortune, C.; Weinstein, J.; Wheeler, M.; Blanchard, F. Air contaminant exposures during the operation of lawn and garden equipment. J. Expo. Sci Environ. Epidemiol 2006, 16, 362-370. [CrossRef] [PubMed]

38. Paton-Walsh, C.; Rayner, P.; Simmons, J.; Fiddes, S.L.; Schofield, R.; Bridgman, H.; Beaupark, S.; Broome, R.; Chambers, S.D.; Chang, L.T.-C.; et al. A clean air plan for Sydney: An overview of the special issue on air quality in New South Wales. Atmosphere 2019, 10, 774. [CrossRef]

39. Marchant-Fuentes, C.; Leiva, V.; Christakos, G.; Cavieres, M.F. Monitoring urban environmental pollution by bivariate control charts: New methodology and case study in Santiago, Chile. Environmetrics 2019, 30, e2551. [CrossRef]

40. Jury, M.R. Meteorology of air pollution in Los Angeles. Atmos. Pollut. Res. 2020, in press. [CrossRef] 
41. Yu, S.; Li, P.; Wang, L.; Wu, Y.; Wang, S.; Liu, K.; Zhu, T.; Zhang, Y.; Hu, M.; Zeng, L.; et al. Mitigation of severe urban haze pollution by a precision air pollution control approach. Sci. Rep. 2018, 8, 1-11. [CrossRef] [PubMed]

42. Hassan, S.K.; Khoder, M.I. Chemical characteristics of atmospheric PM2.5 loads during air pollution episodes in Giza, Egypt. Atmos. Environ. 2017, 150, 346-355. [CrossRef]

43. Smurzyńska, A.; Czekała, W.; Hektus, P.; Marks, S.; Mazurkiewicz, J.; Brzoski, M.; Chełkowski, D.; Kozłowski, K. Poznań air pollution analysis for 2015-2017. J. Ecol. Eng. 2018, 19. [CrossRef]

44. Zijlema, W.L.; Wolf, K.; Emeny, R.; Ladwig, K.H.; Peters, A.; Kongsgård, H.; Hveem, K.; Kvaløy, K.; Yli-Tuomi, T.; Partonen, T.; et al. The association of air pollution and depressed mood in 70,928 individuals from four European cohorts. Int. J. Hyg. Environ. Health 2016, 219, 212-219. [CrossRef] [PubMed]

45. Le Boennec, R.; Salladarré, F. The impact of air pollution and noise on the real estate market. The case of the 2013 European green capital: Nantes, France. Ecol. Econ. 2017, 138, 82-89. [CrossRef]

46. Lichter, A.; Pestel, N.; Sommer, E. Productivity effects of air pollution: Evidence from professional soccer. Labour Econ. 2017, 48, 54-66. [CrossRef]

47. Sack, C.S.; Kaufman, J.D. Air pollution levels and children's lung health. How low do we need to go? Am. J. Respir. Crit. Care Med. 2016, 193, 819-820. [CrossRef] [PubMed]

48. Sanidas, E.; Papadopoulos, G.H.; Velliou, M.; Tsioufis, K.; Barbetseas, J.; Papademetriou, V. Air pollution and arterial hypertension. A new risk factor is in the air. J. Am. Soc. Hyperten 2017, 11, 709-715. [CrossRef] [PubMed]

49. Cheng, I.; Tseng, C.; Wu, J.; Yang, J.; Conroy, S.M.; Shariff-Marco, S.; Li, L.; Hertz, A.; Gomez, S.L.; Marchand, L.L.; et al. Association between ambient air pollution and breast cancer risk: The multiethnic cohort study. Int. J. Cancer 2020, 146, 699-711. [CrossRef] [PubMed]

50. WHO Regional Office for Europe; OECD. Eco-Nomic Cost of the Health Impact of Air Pollution in Europe: Clean Air, Health and Wealth; WHO Regional Office for Europe: Copenhagen, Denmark, 2015.

51. Badyd, A.J.; Grellier, J.; Dabrowiecki, P. Ambient PM2.5 exposure and mortality due to lung cancer and cardiopulmonary diseases in Polish cities. Adv. Exp. Med. Biol. 2017, 944, 9-17. [CrossRef]

52. Lovarelli, D.; Bacenetti, J. Exhaust gases emissions from agricultural tractors: State of the art and future perspectives for machinery operators. Biosyst. Eng. 2019, 186, 204-213. [CrossRef]

53. Peters, S.; de Klerk, N.; Reid, A.; Fritschi, L.; Musk, A.B.; Vermeulen, R. Estimation of quantitative levels of diesel exhaust exposure and the health impact in the contemporary Australian mining industry. Occup. Environ. Med. 2017, 74, 282-289. [CrossRef] [PubMed]

54. Oguntoke, O.; Adeyemi, A. Degradation of urban environment and human health by emissions from fossil-fuel combusting electricity generators in Abeokuta metropolis, Nigeria. Indoor Built Environ. 2017, 26, 538-550. [CrossRef]

55. Brüske-Hohlfeld, I.; Möhner, M.; Ahrens, W.; Pohlabeln, H.; Heinrich, J.; Kreuzer, M.; Jöckel, K.H.; Wichmann, H.E. Lung cancer risk in male workers occupationally exposed to diesel motor emissions in Germany. Am. J. Ind. Med. 1999, 36, 405-414. [CrossRef]

56. McEwan, A.; Brink, M.; Spinelli, R. Efficiency of different machine layouts for chain flail delimbing, debarking and chipping. Forests 2019, 10, 126. [CrossRef]

57. Spinelli, R.; Eliasson, L.; Magagnotti, N. Value retention, service life, use intensity and long-term productivity of wood chippers as obtained from contractor records. Forests 2017, 8, 503. [CrossRef]

58. Spinelli, R.; Cavallo, E.; Eliasson, L.; Facello, A.; Magagnotti, N. The effect of drum design on chipper performance. Renew. Energy 2015, 81, 57-61. [CrossRef]

59. Spinelli, R.; Magagnotti, N. Determining long-term chipper usage, productivity and fuel consumption. Biomass Bioenerg. 2014, 66, 442-449. [CrossRef]

60. Spinelli, R.; Magagnotti, N. Performance of a small-scale chipper for professional rural contractors. Sci. Pract. 2013, 15, 206-213. [CrossRef]

61. Spinelli, R.; Glushkov, S.; Markov, I. Managing chipper knife wear to increase chip quality and reduce chipping cost. Biomass Bioenerg. 2014, 62, 117-122. [CrossRef]

62. Spinelli, R.; Eliasson, L.; Magagnotti, N. Increasing wood fuel processing efficiency by fine-tuning chipper settings. Fuel Process. Technol. 2016, 151, 126-130. [CrossRef]

63. Choi, Y.S.; Cho, M.J.; Paik, S.H.; Mun, H.S.; Kim, D.H.; Han, S.K.; Oh, J.H. Factors affecting the chipping operation based on the screen size of the drum chipper. Forests 2019, 10, 1029. [CrossRef] 
64. Spinelli, R.; Magagnotti, N.; Paletto, G.; Preti, C. Determining the impact of some wood characteristics on the performance of a mobile chipper. Silva Fenn. 2011, 45, 85-95. [CrossRef]

65. Nati, C.; Spinelli, R.; Fabbri, P. Wood chips size distribution in relation to blade wear and screen use. Biomass Bioenerg. 2010, 34, 583-587. [CrossRef]

66. Nati, C.; Spinelli, R. How blade wear of chippers can affect fuel consumption and wood chip size distribution. In Proceedings of the Forest Engeneering: Meeting the Needs of the Society and the Environment, FORMEC 2010, Padova, Italia, 11-14 July 2010; pp. 1-7.

67. Nati, C.; Eliasson, L.; Spinelli, R. Effect of chipper type, biomass type and blade wear on productivity, fuel consumption and product quality. Croat. J. Eng. 2014, 35, 1-7.

68. Nati, C.; Eliasson, L.; Spinelli, R. Fuel consumption and productivity for two tractor-mounted chippers in relation to knife wear and raw material. In Proceedings of the Formec 2011 Conference Pushing the Boundaries with Research and Innovation in Forest Engineering, Graz, Austria, 9-13 October 2011; pp. 1-8.

69. Eliasson, L.; von Hofsten, H.; Johannesson, T.; Spinelli, R.; Thierfelder, T. Effects of sieve size on chipper productivity, fuel consumption and chip size distribution for open drum chippers. Croat. J. Eng. 2015, 36, 11-17.

70. Pochi, D.; Civitarese, V.; Fanigliulo, R.; Spinelli, R.; Pari, L. Effect of poplar fuel wood storage on chipping performance. Fuel Process. Technol. 2015, 134, 116-121. [CrossRef]

71. Ghaffariyan, M.R.; Sessions, J.; Brown, M. Evaluating productivity, cost, chip quality and biomass recovery for a mobile chipper in Australian roadside chipping operations. J. Sci. 2012, 58, 530-535. [CrossRef]

72. Magagnotti, N.; Spinelli, R. Determining the effect of feedstock type and chipping productivity, fuel consumption and quality output. In Proceedings of the Formec 2011 Conference Pushing the Boundaries with Research and Innovation in Forest Engineering, Graz, Austria, 9-13 October 2011; pp. 1-8.

73. Irdla, M.; Padari, A.; Kurvits, V.; Muiste, P. The chipping cost of wood raw material for fuel in Estonian conditions. For. Stud. 2017, 66, 65-74. [CrossRef]

74. Kuptz, D.; Hartmann, H. Throughput rate and energy consumption during wood chip production in relation to raw material, chipper type and machine setting. In Proceedings of the 22nd European Biomass Conference and Exhibition, Hamburg, Germany, 23-26 June 2014.

75. Mihelič, M.; Spinelli, R.; Poje, A. Production of wood chips from logging residue under space-constrained conditions. Croat. J. Eng. 2018, 39, 223-232.

76. Facello, A.; Cavallo, E.; Magagnotti, N.; Paletto, G.; Spinelli, R. The effect of chipper cut length on wood fuel processing performance. Fuel Process. Technol. 2013, 116, 228-233. [CrossRef]

77. Assirelli, A.; Civitarese, V.; Fanigliulo, R.; Pari, L.; Pochi, D.; Santangelo, E.; Spinelli, R. Effect of piece size and tree part on chipper performance. Biomass Bioenerg. 2013, 54, 77-82. [CrossRef]

78. Poje, A.; Spinelli, R.; Magagnotti, N.; Mihelic, M. Exposure to noise in wood chipping operations under the conditions of agro-forestry. Int. J. Ind. Ergon. 2015, 50, 151-157. [CrossRef]

79. Manzone, M.; Spinelli, R. Wood chipping performance of a modified forager. Biomass Bioenerg. 2013, 55, 101-106. [CrossRef]

80. Manzone, M.; Balsari, P. Productivity and woodchip quality of different chippers during poplar plantation harvesting. Biomass Bioenerg. 2015, 83, 278-283. [CrossRef]

81. Mihelič, M.; Spinelli, R.; Magagnotti, N.; Poje, A. Performance of a new industrial chipper for rural contractors. Biomass Bioenerg. 2015, 83, 152-158. [CrossRef]

82. Shahid, L.A.; Amjad, N.; Siddhu, M.A.H. Adaptation and performance evaluation of a tractor operated wood chipper shredder. Pak. J. Agric. Res. 2019, 32, 197-204. [CrossRef]

83. Colantoni, A.; Mazzocchi, F.; Laurendi, V.; Grigolato, S.; Monarca, F.; Monarca, D.; Cecchini, M. Innovative solution for reducing the run-down time of the chipper disc using a brake clamp device. Agriculture 2017, 7, 71. [CrossRef]

84. Manzone, M. Energy consumption and CO2 analysis of different types of chippers used in wood biomass plantations. Appl. Energy 2015, 156, 686-692. [CrossRef]

85. Laitila, J.; Routa, J. Performance of a small and medium sized professional chippers and the impact of storage time on Scots pine (Pinus sylvestris) stem wood chips characteristics. Silva Fenn. 2015. [CrossRef]

86. Han, S.K.; Han, H.S.; Bisson, J.A. Effects of grate size on grinding productivity, fuel consumption, and particle size distribution. Prod. J. 2015, 65, 209-216. [CrossRef] 
87. Jasinskas, A.; Ulozeviciute, I.; Sarauskis, E.; Sakalauskas, A.; Puskunigis, M. Determination of energy plant chopping quality and emissions while burning chaff. Agron. Res. 2011, 9, 49-61.

88. Spinelli, R.; Nati, C.; Sozzi, L.; Magagnotti, N.; Picchi, G. Physical characterization of commercial woodchips on the Italian energy market. Fuel 2011, 90, 2198-2202. [CrossRef]

89. Prada, M.; Martínez-Alonso, C.; Sánchez-García, S.; Canga, E. Analysis of three forest chippers: Productivity, costs and GHG emissions in Northern Spain. J. Clean. Prod. 2015, 101, 238-244. [CrossRef]

90. Pari, L.; Suardi, A.; Del Giudice, A.; Scarfone, A.; Santangelo, E. Influence of chipping system on chipper performance and wood chip particle size obtained from peach prunings. Biomass Bioenerg. 2018, 112, 121-127. [CrossRef]

91. Spinelli, R.; Magagnotti, N. The effect of raw material, cut length, and chip discharge on the performance of an industrial chipper. Prod. J. 2012, 62, 584-589. [CrossRef]

92. Bello, S.R.; Onilude, M.A. Force relations and dynamics of cutting knife in a vertical disc mobile wood chipper. Leonardo Electron. J. Pract. Technol. 2011, 18, 17-34.

93. Rebaki24-Catalog. Available online: https://rebaki24.pl/pl/ (accessed on 6 January 2018).

94. German GX 390-Catalog. Available online: http://www.i-ogrod.pl/silnik-spalinowy-german-13km-gx390zageszczarka-p-1481.html (accessed on 6 January 2018).

95. Carburettor LPG. Available online: https://archiwum.allegro.pl/oferta/gaznik-lpg-cng-dwufunkcyjny-168fagregat-gx160-390-i7476479018.html (accessed on 6 January 2018).

96. Merkisz, J.; Dobrzyński, M.; Kozak, M.; Lijewski, P.; Fuć, P. Environmental aspects of the use of cng in public urban transport. Altern. Fuels Technol. Environ. Cond. 2016. [CrossRef]

97. Warguła, Ł.; Waluś, K.J.; Krawiec, P.; Kukla, M. Research of the ignition advance angle characteristics on the example of a German GX 390 combustion engine. Autobusy Technol. Eksploat. Syst. Transp. 2017, 12, 1387-1391.

98. Warguła, Ł.; Kaczmarzyk, P.; Dziechciarz, A. The assessment of fire risk of non-road mobile wood chopping machines. J. Res. Appl. Agric. Eng. 2019, 64, 58-64.

99. Serdecki, W. Testing of Internal Combustion Engines; Poznan University of Technology: Poznań, Poland, 2012; ISBN 978-83-7775-105-3.

100. Rychlik, A. Commercial vehicles fuel consumption measurement methods. Maint. Reliab. 2006, 4, 37-41.

101. ISO; IEC; OIML. Guide to the Expression of Uncertainty in Measurement; International Electrotechnical Commission: Geneva, Switzerland, 1995.

102. ISO. International Vocabulary of Basic and General Terms in Metrology; International Organization for Standardization: Geneva, Switzerland, 1993.

103. ISO. International Standard ISO 3534-1: (1993) (E/F) Statistics-Vocabulary and Symbols; International Organization for Standardization: Geneva, Switzerland, 1993.

104. Kendall, M.G.; Stuart, A. The Advanced Theory of Statistics; Charles Griffin \& Company Limited: London, UK, 1966.

105. Kołodziej, S.; Graba, M.; Bieniek, A. Power efficiency of a internal combustion engine powered by liquefied petroleum gas. TTS Technol. Transp. Szyn. 2015, 22, 796-799.

106. Małek, A. The requirements for emission standards Euro 5 for vehicles fueled by LPG. Autobusy Technol. Eksploat. Syst. Transp. 2011, 12, 289-294.

107. Abramek, K.F.; Uzdowski, M. Some aspects of exploitation vehicles using gaseous fuels. Autobusy Technol. Eksploat. Syst. Transp. 2012, 13, 39-42.

108. Rahman, S. Another perspective on gasoline price responses to crude oil price changes. Energy Econ. 2016, 55, 10-18. [CrossRef]

109. Sjoquist, D.L.; Tang, X. Differential effects of federal and state gasoline taxes on gasoline consumption. Proc. Annu. Conf. Tax. Minutes Annu. Meet. Natl. Tax Assoc. 2017, 110, 1-10.

110. Noel, M.D. Calendar synchronization of gasoline price increases. J. Econ. Manag. Strategy 2019, $28,355-370$. [CrossRef]

111. Koay, L.K.; Sah, M.J.M.; Othman, R.B. Comparative study of fuel consumption, acceleration and emission for road vehicle using LPG or gasoline. Adv. Eng. Process. Technol. 2019, 77-87. [CrossRef]

112. Park, G.; Mun, S.; Hong, H.; Chung, T.; Jung, S.; Kim, S.; Seo, S.; Kim, J.; Lee, J.; Kim, K.; et al. Characterization of emission factors concerning gasoline, LPG, and diesel vehicles via transient chassis-dynamometer tests. Appl. Sci. 2019, 9, 1573. [CrossRef] 
113. Szpica, D. Coefficient of engine flexibility as a basis for the assessment of vehicle tractive performance. Chin. J. Mech. Eng. 2019, 32, 1-12. [CrossRef]

114. Szpica, D.; Piwnik, J.; Sidorowicz, M. The motion storage characteristics as the indicator of stability of internal combustion engine-Receiver cooperation. Mechanika 2014, 20, 108-112. [CrossRef]

(C) 2020 by the authors. Licensee MDPI, Basel, Switzerland. This article is an open access article distributed under the terms and conditions of the Creative Commons Attribution (CC BY) license (http://creativecommons.org/licenses/by/4.0/). 